\title{
The Abundance of some Pathogenic Bacteria In Mangrove Habitats of Paraiba do Norte Estuary and Crabmeat Contamination of Mangrove Crab Ucides cordatus
}

\author{
Teresa Cristina Soares de Lima Grisi ${ }^{1,2}$ and Krystyna Gorlach-Lira ${ }^{2 *}$ \\ ${ }^{I}$ Centro de Tecnologia; Universidade Federal da Paraíba; Cidade Universitária, s/n; 58051-900; João Pessoa - PB \\ - Brasil. ${ }^{2}$ Departamento de Biologia Molecular; Centro de Ciências Exatas e da Natureza; Universidade Federal da \\ Paraíba; Cidade Universitária, s/n; 58051-900; João Pessoa - PB - Brasil
}

\begin{abstract}
Study on mangrove water and sediment of Paraiba do Norte river (Northeastern Brazil) and crabmeat of Ucides cordatus was carried to investigate the relation between the abundance of bacteria in the mangrove habitat and in the crabmeat. Simultaneous collection of samples of water, sediment and crabs (U. cordatus) was done during the rainy and dry seasons at two areas of mangroves that differed in influence of tide and sewage discharge. The numbers of total heterotrophic bacteria in the mangrove water were between 0.04 and $6 \log C F U 100 \mathrm{~mL}^{-1}$, and in the sediment between 5 and $6 \log C F U g^{-1}$. The location closer to waste discharge showed higher incidence of total heterotrophic bacteria, coliforms, Staphylococcus aureus and Salmonella spp. The counts of total heterotrophic bacteria in the crabmeat varied from 1.3 to $4.4 \log C F U g^{-1}$, and did not differ significantly between the locations analysed. No crabmeat sample showed the presence of coliforms, S. aureus and Salmonella spp.
\end{abstract}

Key words: Mangrove ecosystem, bacteria, Ucides cordatus, crabmeat, contamination

\section{INTRODUCTION}

Brazil has ca. $8500 \mathrm{~km}$ of coastline with the second largest mangrove area on the earth (Kjerfve et al., 1997). These ecosystems are the first to suffer with urbanization and industrialization at coastal regions, and over the years extensive mangrove ecosystems disappeared, putting an end to many of their important functions. Therefore, the anthropogenic influence in the estuaries must be monitored, since they act as a breeding and feeding ground, nursery and refuge of numerous marine dwellers; and in addition, they can serve as buffers against coastal erosion, for retaining some pollutants, and are important for fishery (Cotano and Villate, 2006). The mangrove areas of Paraíba do Norte river, state of Paraíba, Northeastern Brazil, receive effluents containing mainly domestic and municipal sewage, and in lower quantity wastes from alcohol and sugar industry. Sewage sludge poses direct or indirect effects on mangrove ecosystems and organisms, contributing for the decline of fishery in the region (CAGEPA, 1997; IBAMA, 1994). Sewage effluent entering coastal water contains diverse pollutants including viral and bacterial pathogens, such as Vibrio cholerae, Staphylococcus aureus, Salmonella spp., Pseudomonas aeruginosa, among others, toxic chemicals, and a variety of organic and inorganic wastes (Islam and Tanaka, 2004).

\footnotetext{
*Author for correspondence: krysgl@dbm.ufpb.br
} 
Among large and diverse range of mangrove products in the Brazilian north and north-eastern estuaries, the mangrove crab Ucides cordatus is the most harvested and has the highest commercial and subsistence importance to rural households of the coastal population (Hattori and Pineiro, 2003; Glaser and Diele, 2004; Dalabona et al., 2005). The crabs are hand-picked and transported to markets alive or they are cooked to obtain meat destined for markets and restaurants. The quality of environment may affect the quantity and diversity of the microorganisms present on the surface of seafood and fishery products, as well as the mode of collection and processing of products may cause increase of microbial contamination (Jackson et al., 1997; Ristori et al., 2007). Pathogenic bacteria from genera Salmonella, Staphylococcus, Vibrio and Listeria, were frequently found in crabmeat (Degnan et al., 1994; Ellender et al., 1995; Vieira et al., 2004).

The present work aimed to study the relation between the abundance of some pathogenic bacteria in water and sediment of mangrove habitats of Paraíba do Norte estuary (Northeastern Brazil) and the level of contamination of the meat obtained from $U$. cordatus, collected in the mangrove forest. The effect of cooking time of crabs on the bacterial abundance in the crabmeat was also evaluated.

\section{MATERIAL AND METHODS}

\section{Study site and sampling}

The Paraíba do Norte estuary $\left(6^{\circ} 51^{\prime} 31^{\prime \prime}\right.$ to $8^{\circ} 26^{\prime} 21^{\prime \prime} \mathrm{S}$ and $34^{\circ} 48^{\prime} 35^{\prime \prime}$ to $37^{\circ} 2^{\prime} 15^{\prime \prime} \mathrm{W}$ ) is located in the northeastern part of Brazil at the State of Paraíba. The study area comprise two sites of mangrove forest along the estuary analysed. The sampling site Camboa Grande (CG; a shallow entrance of the river in the mangrove area) was localized at ca. $0.5 \mathrm{~km}$ distant from the discharge of sewage. The sampling site Ilha do Stuart (IS; a small island) was situated in the Paraíba do Norte course, at about $3.5 \mathrm{~km}$ distance from the waste discharge and $12 \mathrm{~km}$ from the coast, where the estuary bordered with the open ocean. The region studied is characterized by tropical climate with marked seasonality and most rainfall between May and August (rainy season).

The samples of water and sediment were collected monthly during rainy season (May - July 1998) and dry season (December 1998 - February 1999) at two sampling sites, always during the high tide period. The water samples were collected in sterile glass bottles, and sediment samples were taken from $0-10 \mathrm{~cm}$ depth and kept in plastic bags. Samples were maintained at $\pm 4{ }^{\circ} \mathrm{C}$ and analysed within six hours after sampling. The collection of $U$. cordatus was done simultaneously: 4 to 6 crabs, depending on their size, were sampled at each study site and transported alive to the laboratory for further analysis. Approximately 100 mangrove crabs were collected and processed during the study.

\section{Sample preparation}

The water samples were agitated and the decimal dilutions of $1 \mathrm{~mL}$ aliquot were done using sterile saline solution $(0.85 \%)$ (APHA, 2005). The samples of $10 \mathrm{~g}$ of sediment were added to $90 \mathrm{~mL}$ of Ringer solution (Lorch et al., 1995), agitated for 20 minutes $(150 \mathrm{rpm}$.) and diluted serially. The crabs were washed under a flux of tap water for removing all the residues from their carapaces. They were killed by perforation of their cephalothorax and boiled for 30 or 60 minutes. The $10 \mathrm{~g}$ meat was obtained from cephalothorax and claws and agitated in $90 \mathrm{~mL}$ of peptone water $(0.1 \%)$ for 20 minutes $(150 \mathrm{rpm})$, and decimal dilutions were done (APHA, 2001).

\section{Physico-chemical characterization of water and sediment samples}

The temperature, $\mathrm{pH}$, and salinity of water and sediment samples were measured. Dissolved oxygen (DO) and biochemical oxygen demand (BOD) were analysed in the water samples, and percent moisture in sediment samples. These variables were measured according to APHA (2005) and Foster (1995). The sediment was analysed for total organic matter (C), total $\mathrm{N}, \mathrm{Na}$, $\mathrm{Ca}, \mathrm{K}, \mathrm{P}$ and $\mathrm{Mg}$ by the Department of Chemistry Engineering at the Federal University of Pernambuco in Recife, state of Pernambuco, Brazil.

\section{Microbiological analysis of water, sediment and crabmeat samples}

The number of total heterotrophic bacteria was estimated by plating (pour plate) serial dilutions on Plate Count Agar (PCA, Oxoid). The counts were done after $48 \mathrm{~h}$ of incubation at $35^{\circ} \mathrm{C}$ (APHA, 2001; APHA, 2005). Total and faecal coliform numbers were determined by the technique of the Most Probable Number (MPN) according to 
APHA (2005). The presence of Escherichia coli was estimated by using Fluorocult ${ }^{\circledR}$ Agar VRB (Merck) (Jay et al., 2005). The counts of $S$. aureus were performed on the Baird Parker medium (Difco) according to APHA (2001). The confirmation of $S$. aureus was done by isolating three typical and three atypical colonies and by the characterization of isolates by Gram staining, catalase, coagulase and DNA-se production tests. The presence of Salmonella spp. was evaluated according to APHA (2005). For the Salmonella confirmation, the five isolates of each sample were characterized by using the following tests: Gram staining, urease production (Urea Broth R medium - Difco), the reaction in the Triple Sugar Iron Agar (Vetec) and in the Lisine Iron Agar (Difco) and IMViC test (Difco). The strains were submitted to antigenic characterization by using anti-Salmonella $\mathrm{O}$ polyvalent somatic sore (Probac). The following standard strains were used as reference: E. coli ATCC 25922, Enterobacter aerogenes ATCC 13048, S. aureus ATCC 25923, S. epidermidis ATCC 14990, Salmonella enteritidis MM 6247, and Pseudomonas aeruginosa IT 2633.

\section{Statistical analysis}

Mean values and standard errors were generated for each physico-chemical variable and each microbial group. The one-way analysis of variance (ANOVA) was performed on the physical and chemical variables and counts of bacteria (Log $\mathrm{CFU}$ ). Comparisons having significant $\mathrm{F}$ values $(\mathrm{p} \leq 0.05)$ were further compared using Tukey's HSD test. The software used for the computation of statistics was Statistica (version 5).

\section{RESULTS}

Physical and chemical characteristics of mangrove habitat water and sediment

Bacterial abundance and physico-chemical variables differed between the sampling sites of mangrove habitats of the Paraíba do Norte river. The water of site CG, closer to the waste discharge and more distant from the river estuary, showed significantly lower salinity and less dissolved oxygen than IS location (Table 1). The latter showed higher value of BOD during the experiment, but the significant difference of BOD between sites was observed only in the dry season. The salinity increased drastically in the estuary and adjacent channels in the dry season, from about 12 to $18 \%$ and from 25 to $33 \%$ at locations CG and IS, respectively (Table 1). The salinity of sediment was 2-6 times lower than of water, and during the dry season, it was significantly higher at location $\mathrm{CG}$ (Table 2). The temperature and $\mathrm{pH}$ of water and sediment samples did not differ significantly between the sites analysed (Tables 1 and 2). The organic matter content in the sediment of both the sites was similar, but total nitrogen content was much lower in IS site than CG site (Table 1). The content of other parameters analyzed was also lower in IS site sediment.

Table 1 - Physico-chemical variables of water.

\begin{tabular}{lccccc}
\hline Sampling site & Temperature $\left({ }^{\circ} \mathbf{C}\right)$ & Salinity $(\%)$ & pH & DO $(\mathbf{m g} / \mathbf{L})$ & BOD $_{\mathbf{5}}(\mathbf{m g} / \mathbf{L})$ \\
\hline Rainy season & & & & & \\
$C G$ & $27.3 \pm 1.33 \mathrm{a} *$ & $11.67 \pm 2.08 \mathrm{a}$ & $7.71 \pm 0.27 \mathrm{a}$ & $2.15 \pm 0.21 \mathrm{a}$ & $17.25 \pm 5.02 \mathrm{a}$ \\
IS & $27.5 \pm 1.32 \mathrm{a}$ & $18.17 \pm 1.26 \mathrm{ab}$ & $7.57 \pm 0.11 \mathrm{a}$ & $7.80 \pm 0.14 \mathrm{~b}$ & $7.80 \pm 2.26 \mathrm{ac}$ \\
Dry season & & & & & \\
$C G$ & $29.7 \pm 1.53 \mathrm{a}$ & $25.17 \pm 4.48 \mathrm{~b}$ & $7.40 \pm 0.63 \mathrm{a}$ & $0.00 \pm 0.00 \mathrm{c}$ & $20.1 \pm 6.75 \mathrm{ab}$ \\
IS & $29.7 \pm 0.58 \mathrm{a}$ & $32.67 \pm 2.08 \mathrm{c}$ & $7.43 \pm 0.47 \mathrm{a}$ & $6.40 \pm 0.26 \mathrm{~d}$ & $6.93 \pm 3.27 \mathrm{ac}$ \\
\hline
\end{tabular}

*The values marked with different letters are significantly different $(\mathrm{P}<0.05)$. 
Table 2 - Physico-chemical variables of sediment of Paraíba do Norte river mangrove area.

\begin{tabular}{lcccc}
\hline \multicolumn{1}{c}{ Sampling site } & Temperature $\left({ }^{\circ} \mathbf{C}\right)$ & Salinity $(\%)$ & pH & Humidity (\%) \\
\hline Rainy season & & & & \\
CG & $26.5 \pm 2.18 \mathrm{a}^{*}$ & $5.66 \pm 1.15 \mathrm{ac}$ & $6.89 \pm 0.56$ & $57.73 \pm 2.49 \mathrm{a}$ \\
IS & $26.8 \pm 2.02 \mathrm{a}$ & $3.50 \pm 0.50 \mathrm{ac}$ & $6.33 \pm 0.71$ & $33.34 \pm 6.47 \mathrm{~b}$ \\
Dry season & & & & \\
CG & $29.0 \pm 2.65 \mathrm{a}$ & $9.00 \pm 1.00 \mathrm{~b}$ & $7.14 \pm 0.71$ & $61.86 \pm 4.93 \mathrm{c}$ \\
IS & $28.2 \pm 1.04 \mathrm{a}$ & $5.66 \pm 0.57 \mathrm{c}$ & $7.30 \pm 0.56$ & $31.23 \pm 3.52 \mathrm{bd}$ \\
\hline
\end{tabular}

*The values marked with different letters are significantly different $(\mathrm{P}<0.05)$.

\section{Abundance of bacteria in mangrove habitat water and sediment}

Both the locations showed variation in the content of bacteria in water and sediment. The numbers of heterotrophic bacteria in the water of site CG varied between 2 and $4 \log \mathrm{CFU} 100 \mathrm{~mL}^{-1}$, while the variation of their counts were higher at site IS $\left(0.04\right.$ - $6 \log$ CFU $\left.100 \mathrm{~mL}^{-1}\right)$. The average numbers of bacteria in the water of site $\mathrm{CG}$ were 3.2 and $3.3 \log$ CFU $100 \mathrm{~mL}^{-1}$ in the rainy and dry season, respectively, while their counts were lower at site IS, especially in the dry season $(0.2 \mathrm{log}$ CFU $100 \mathrm{~mL}^{-1}$ ) (Fig. 1). The counts of heterotrophic bacteria in the sediment were similar at both the locations and averaged 5.5-6.3 log
CFU g - $^{-1}$ Fig. 2).

The population size of heterotrophic bacteria in the mangrove area did not differ significantly between the sampling sites and seasons. The higher abundance of total and faecal coliforms was observed at the mangrove area closer to the waste discharge (site CG), throughout the study period (Figs. 1 and 2). No coliforms and less total heterotrophic bacteria were observed in the dry season in water samples of the site IS, where a decrease of coliforms number in the sediment was observed. E. coli was found in all the water and sediment samples of the site CG, while its incidence was lower at the site IS (50\% positive samples) (Table 4).

Table 3 - Chemical analysis of sediment of Paraiba do Norte river mangrove area.

\begin{tabular}{ccccccccc}
\hline \multirow{2}{*}{ Sampling site } & $\mathbf{C}$ & $\mathbf{N}$ & $\mathbf{P}$ & $\mathbf{K}$ & $\mathbf{N a}$ & $\mathbf{C a}$ & $\mathbf{M g}$ \\
\cline { 2 - 8 } & & & & $\mathbf{( \% )}$ & & & \\
\hline CG & 0.25 & 0.20 & 0.20 & 3.91 & 1.69 & 2.50 & 5.43 \\
IS & 0.23 & $<0.01$ & 0.07 & 2.10 & 1.08 & 1.80 & 2.84 \\
\hline
\end{tabular}

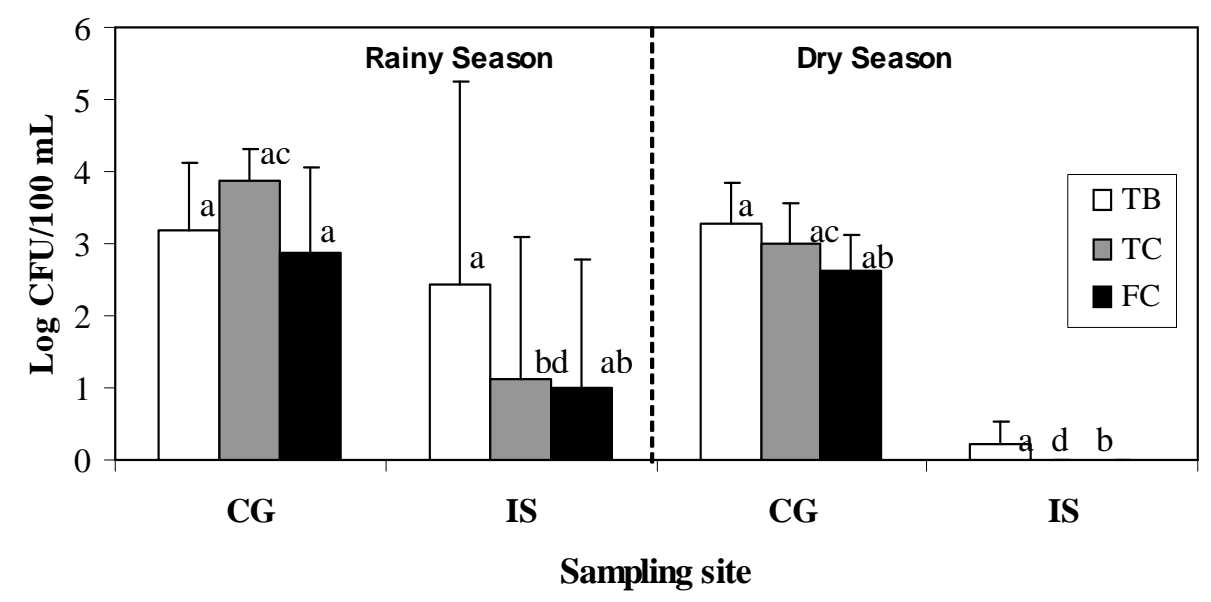

Figure 1 - Total heterotrophic bacteria (TB), total (TC) and faecal (FC) coliforms in water of Paraíba do Norte river mangrove areas. The columns marked with different letter are significantly different $(\mathrm{p}<0.05)$. 


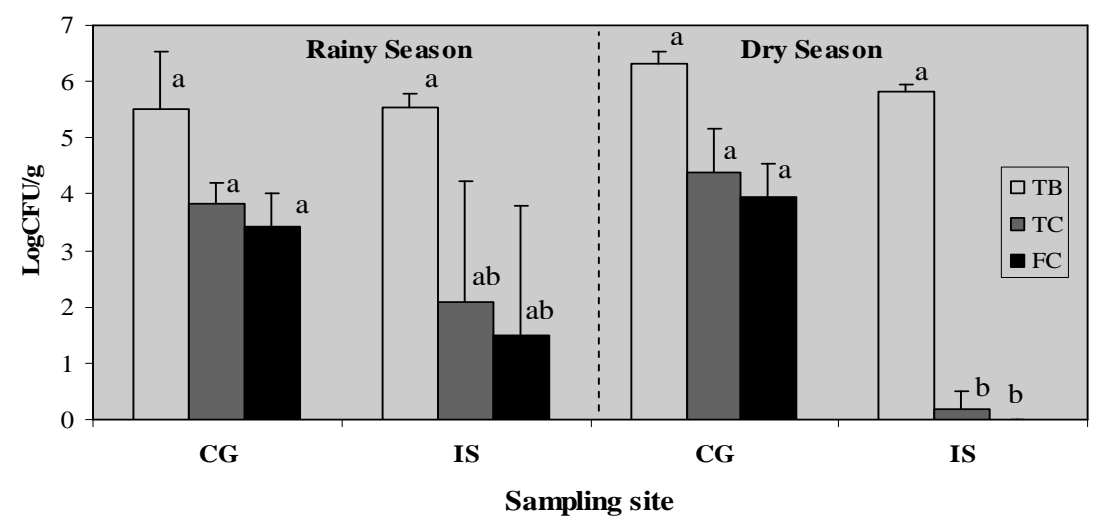

Figure 2 - Total heterotrophic bacteria (TB), total (TC) and faecal (FC) coliforms in sediment of Paraíba do Norte river mangrove areas. The columns marked with different letter are significantly different $(\mathrm{p}<0.05)$.

The incidence of $S$. aureus and Salmonella also varied in the mangrove areas analyzed (Table 4). Higher numbers of samples contaminated with $S$. aureus were obtained from the location CG, and during the dry season, the percentage of contaminated samples increased $(75 \%)$ in comparison to rainy season (16.7\%). Salmonella spp. were found in $25 \%$ and $16.7 \%$ of water and sediment samples, respectively, all collected at location CG (Table 4). Among 149 strains isolated from mangrove habitat water (72) and sediment (77), seven were identified as Salmonella spp. All Salmonella strains were isolated from site CG, three strains from water and four from sediment. Among other identified bacterial strains (92), the most frequent were Enterobacter (42\%), Proteus (22\%) and Pseudomonas (21\%), and the least common were Escherichia (8\%), Providencia (5\%), and Citrobacter (2\%).

\section{Bacterial contamination of $U$. cordatus crabmeat}

The counts of heterotrophic bacteria in the meat of $U$. cordatus collected in the Paraíba do Norte mangrove habitats varied from 1.3 to $4.4 \log \mathrm{CFU}$ $\mathrm{g}^{-1}$ and did not differ significantly between the locations analysed (Table 5). The influence of season on the number of total heterotrophic bacteria in crabmeat was significant $(\mathrm{P}<0.05)$.

The meat of crabs captured in the dry season showed higher quantity of total bacteria than the crabs collected in the rainy season. The numbers of heterotrophic bacteria in crabmeat cooked for 60 minutes were slightly lower than in samples cooked for 30 minutes (Table 5). No crabmeat sample showed the presence of coliforms, $S$. aureus and Salmonella spp. The majority of 40 strains presumptive for Salmonella spp. isolaled from crabmeat were identified as Enterobacter spp. (53\%) and Pseudomonas spp. (33\%).

Table 4 - The presence of pathogenic bacteria in samples of water, sediment and crab meat of Ucides cordatus collected at the mangrove areas of Paraiba do Norte river.

\begin{tabular}{|c|c|c|c|c|c|c|}
\hline \multirow{2}{*}{ Sampling site } & \multirow{2}{*}{$\begin{array}{c}\text { Number of } \\
\text { samples }\end{array}$} & \multicolumn{2}{|c|}{ E. coli } & \multicolumn{2}{|c|}{ S. aureus } & \multirow{2}{*}{$\begin{array}{c}\begin{array}{c}\text { Salmonella } \\
\text { spp. }\end{array} \\
\text { Positive } \\
\text { samples }\end{array}$} \\
\hline & & $\begin{array}{l}\text { Positive } \\
\text { samples }\end{array}$ & Dilution $^{a}$ & $\begin{array}{l}\text { Positive } \\
\text { samples }\end{array}$ & $\begin{array}{c}\text { Log CFU/ } \\
100 \mathrm{~mL}\end{array}$ & \\
\hline \multicolumn{7}{|l|}{ CG } \\
\hline Water & 6 & 6 & $10^{-3}-10^{-5}$ & 3 & $2.0-3.2$ & 3 \\
\hline Sediment & 6 & 6 & $10^{-1}-10^{-4}$ & 4 & $1.8-4.1$ & 2 \\
\hline Crabmeat & 6 & 0 & - & 0 & - & 0 \\
\hline \multicolumn{7}{|l|}{ IS } \\
\hline Water & 6 & 5 & $10 \mathrm{~mL}-10^{-3}$ & 1 & 1.3 & 0 \\
\hline Sediment & 6 & 1 & $10^{-2}$ & 3 & $2.4-2.9$ & 0 \\
\hline Crabmeat & 6 & 0 & - & 0 & - & 0 \\
\hline
\end{tabular}

a - The highest dilution of sample or the smallest volume with $E$. coli presence. 
Table 5 - Summary results for counts of heterotrophic bacteria in crabmeat of Ucides cordatus (Log CFU $\mathrm{g}^{-1}$ ) cooked for 30 and 60 minutes.

\begin{tabular}{|c|c|c|c|c|c|}
\hline Sampling site & Mean & Median & Minimum & Maximum & Standard deviation \\
\hline \multicolumn{6}{|l|}{ CG } \\
\hline $30 \mathrm{~min}$ & $3.40 a^{*}$ & 3.62 & 2.39 & 4.15 & 0.687 \\
\hline $60 \mathrm{~min}$ & $3.10 \mathrm{a}$ & 3.05 & 2.58 & 3.91 & 0.549 \\
\hline \multicolumn{6}{|l|}{ IS } \\
\hline $30 \mathrm{~min}$ & $2.95 \mathrm{a}$ & 3.14 & 1.18 & 4.38 & 1.133 \\
\hline $60 \mathrm{~min}$ & $2.66 \mathrm{a}$ & 2.79 & 1.30 & 3.98 & 1.016 \\
\hline
\end{tabular}

*The values marked with different letters are significantly different $(\mathrm{P}<0.05)$.

\section{DISCUSSION}

The water of the bays and estuaries usually show high microbial populations composed by the autochthon groups, as well as microorganisms introduced to these areas, principally with the discharge of domestic and industrial wastes. The release of effluents contributes greatly to the increase of bacterial population as consequence of introduction of contaminant species and high quantity of organic residues (Tam, 1998; Cotano and Villate, 2006). The contamination of aquatic environments by effluents creates two kinds of public health problems: the first is related to the risks associated with the primary contact (bathing), and the other related to the fishing and consuming of animals from the polluted area.

Since long the Paraíba do Norte river suffers from degradation caused by the non-treated domestic wastes, agriculture and industrial residues discharged to the mangrove area. The present work showed that the two mangrove sites along the Paraíba do Norte estuary being under different level of sewage influence, differed in physical, chemical and microbiological characteristics of the water and sediment. The sampling site CG, closer to the local of sewage effluent, showed higher incidence of total heterotrophic bacteria, coliforms, and pathogenic bacteria, such as Salmonella and S. aureus. The results obtained showed a decrease of contaminant microorganisms in the Paraíba do Norte river downstream the discharge point. Similarly, Al-Sayed et al. (2005) reported that the distribution of total and faecal coliforms in water showed a distinctive decreasing pattern downstream the Arabian Gulf mangrove sites.

The lower influence of sewage, as well as the increase of salinity might have been responsible for the decrease of microbial population downstream the river. Salinity affects the bacterial community, as Reheinheimer (1997) reported in the study of the Elbe estuary in the west Baltic Sea. Variations of salinity depend on tide and sewage discharge (Corredor and Morell, 1994; Tam, 1998), and they might affect the retention of pollutants and the microbial responses in the wastewater discharge.

The numbers of total heterotrophic bacteria were more stable in the sediment than in the mangrove area water. Davies et al. (1995) observed similar relation between the size of bacterial population in the water and sediment, considering that adsorption of microorganisms on the sediment particles might give a sort of protection from the bactericidal effect of solar radiation, high salinity, toxicity, and heavy metals.

The occurrence of pathogenic bacteria was higher in the water and sediment of location CG, and Salmonella spp. was detected only at this site. $S$. aureus was detected in $33 \%$ of water samples and $58 \%$ of sediment samples, with higher frequency of contaminated samples in the dry season at CG site. Aslan-Yilmaz et al., (2004) observed that $S$. aureus was detected in the water even if the number of coliforms was low, an aspect in agreement with its higher resistance to chlorine treatment and variation of salinity between the estuary and ocean.

The environmental habitat and the processing practice are the factors determining the initial contamination of seafood fish, crustacean, oysters, and molluscs (Jackson et al., 1997; Ristori et al., 2007). Raw products are initially contaminated with a wide variety of microorganisms, but the microbes that colonize the food and grow to high numbers are selected by various intrinsic and extrinsic variables (Gram and Huss, 1994). Artisanal fishery is quite common in the estuaries of north and northeast Brazil, where fishermen capture diverse kinds of fishes, oysters, and crustaceans (IBAMA, 1994; Wolff et al., 2000). 
Crabs captured by the crab gatherers in the region studied, are usually processed in inadequate hygienic conditions, resulting in contamination of the crabmeat (Lima and Gorlach-Lira, 2007). Moreover, the variables analysed showed that one of the location studied (site CG) was not proper for the extraction of fishery products, according to the Brazilian legislation (CONAMA, 2005). The variables of the site IS were, in general, within the recommended levels; however, the values of BOD in some sampling periods were higher than required for a good water quality.

When the crabs are collected, they are usually covered with mud, and then washed with mangrove water, that does not eliminate the contamination by saprophytic and pathogenic bacteria. The crabs must be cooked before obtaining the meat; however, depending on the cooking period, many bacteria may survive or they may be introduced during the meat manipulation (Thomas et al., 2007; Jay et al., 2005). These bacteria may proliferate even under the low temperature and contribute to the spoilage of the crabmeat (Robson et al., 2007). The counts of heterotrophic bacteria in the crabmeat of $U$. cordatus collected in the Paraíba do Norte mangrove areas and processed in the laboratory were always below $5 \log \mathrm{CFU} \mathrm{g}{ }^{-1}$. The crabmeat processed under the laboratory conditions showed neither coliforms nor Salmonella spp. and $S$. aureus. In spite of differences between the bacterial abundance in the water and sediment of the analysed locations, the contamination level of crabmeat was similar for both the sites, and did not reflect the distribution pattern of bacteria in the mangrove crab habitat.

It is interesting to compare the results of the present work with the results obtained from the samples of crabmeat commercialized in a market at João Pessoa and another at Cabedelo (both cities in the state of Paraíba), which showed that the samples were frequently contaminated by $S$. aureus and the numbers of heterotrophic bacteria were always higher than $8 \log \mathrm{CFU} \mathrm{g}{ }^{-1}$ (Lima and Gorlach-Lira, 2007). Vieira et al. (2004) found Salmonella species in $15 \%$ of $U$. cordatus samples and detected high numbers of Vibrio spp. in the crabmeat commercialized at the Fortaleza market, state of Ceará, Brazil. Better quality of crabmeat processed in the laboratory than crabmeat commercialized at markets indicated that the way of crabmeat processing and handling might greatly increase the contamination level of this product.

\section{ACKNOWLEDGMENTS}

The authors would like to acknowledge CPPCTA (Curso de Pós-Graduação em Ciência e Tecnologia de Alimentos) and $\mathrm{CNPq}$ for financial support, and special thanks to Dr. Breno Grisi (Depto de Sistemática e Ecologia - UFPB) for revision of the manuscript.

\section{RESUMO}

O estudo sobre água e sedimento do mangue do rio Paraíba do Norte (Nordeste do Brasil) e carne de caranguejo-uçá (Ucides cordatus) foi conduzido para investigar a relação entre a abundância de bactérias heterotróficas totais e patogênicas no ambiente e na carne de caranguejo. As amostras de água, sedimento e caranguejos $U$. cordatus foram coletadas simultaneamente em duas áreas do manguezal que diferiam em influencia da maré e do esgoto lançado no mangue. $\mathrm{O}$ número de bactérias heterotróficas totais nas amostras de água do mangue variaram de 0,04 a $6 \log$ UFC $100 \mathrm{~mL}^{-}$ 1 , e no sedimento de 5 a $6 \log$ UFC g ${ }^{-1}$. Em local mais próximo a desembocadura do esgoto evidenciou-se maior incidência de bactérias heterotróficas totais, coliformes, Staphylococcus aureus e Salmonella spp. As contagens de bactérias totais nas amostras da carne de caranguejo variaram de 1,3 a 4,4 $\log \mathrm{UFC}^{-1}$, não diferindo estatisticamente entre as áreas estudadas. Nenhuma amostra da carne de caranguejo apresentou coliformes, S. aureus e Salmonella spp.

\section{REFERENCES}

Al-Sayed, H.A., Ghanem, E.H., Saleh, K.M. (2005), Bacterial community and some physico-chemical characteristics in a subtropical mangrove environment in Bahrain. Mar. Poll. Bull., 50, 147-155.

APHA (2005) Standard Methods for the Examination of Water and Wastewater, 21th ed., Washington. APHA (2001), Compendium of Methods for the Microbiological Examination of Foods, 4th ed., Washington.

Aslan-Yılmaz, A., Okuş, E., Övez, S. (2004), Bacteriological indicators of anthropogenic impact prior to and during the recovery of water quality in an extremely polluted estuary, Golden Horn, Turkey. Mar. Poll. Bull., 49, 951-958.

CAGEPA. Companhia de Água e Esgoto da Paraíba (1997), Relatório - Sistema de coleta e tratamento de esgotos operados pela CAGEPA/PB. 
CONAMA. Conselho Nacional do Meio Ambiente. Resolução $357 \quad$ (2005), Disponível em:<http://www.siam.mg.gov.br/sla/download. pdf?idNorma=2747 > . Acesso em: 14/03/2007.

Corredor, J.E., and Morell, J.M. (1994) Nitrate depuration of secondary sewage effluents in mangrove sediments. Estuaries, 17, 295-300.

Cotano, U. and Villate, F. (2006), Anthropogenic influence on the organic fraction of sediments in two contrasting estuaries: a biochemical approach. Mar. Poll. Bull., 52(4), 404-14.

Dallabona, G., Silva, J. L., Pinheiro, M.A.A. (2005), Size at morphological maturity of Ucides cordatus (Linnaeus, 1763) (Brachyura, Ocypodidae) in the Laranjeiras Bay, Southern Brazil. Braz. Arch. Biol. Tech., 48(1), 139-145.

Davies, C.M., Long, J.A.H., Donald, M., Ashbolt, N.J. (1995), Survival of fecal microorganisms in marine and freshwater sediments. Appl. Environ. Microbiol., 61, 1888-1896.

Degnan, A.J., Kaspar, C.W., Otwell, W.S., Tamplin, M.L., Luchansky, J.B. (1994), Evalution of lactic acid bacterium fermentation products and food-grade chemicals to control Listeria monocytogenes in blue crab (Callinectes sapidus) meat. Appl. Environ. Microbiol., 60, 3198-3203.

Ellender, R.D., Liepin, H., Sharp, S.L., Tettleton, R.P. (1995), Isolation, enumeration, and identification of gram-positive cocci from frozen crabmeat. J. Food PROTEC., 58(8), 853-857.

Foster, J., (1995), Soil physical analysis. In: Alef, K. and Naninipieri, P. (Eds.). Methods in applied soil microbiology and biochemistry. Academic Press, London. pp. 105-121.

Glaser, M., and Diele, K. (2004), Asymmetric outcomes: assessing central aspects of the biological,

economic and social sustainability of a mangrove crab fishery, Ucides cordatus (Ocypodidae), in North Brazil. Ecol. Econ., 49, 131-142.

Gram, L. and Huss, H.H. (1994) Microbiological spoilage of fish and fish products. Int. J. Food Microbiol., 33, 121-137.

Hattori, G.Y. and Pinheiro, M.A.A. (2003), Fertilidade do Caranguejo de mangue Ucides cordatus (Linnaeus) (Crustacea, Brachyura, Ocypodidae), em Iguape (São Paulo, Brasil). Rev. Bras. Zoo., 20(2), 309-313.

IBAMA. Instituto Brasileiro do Meio Ambiente e dos Recursos Naturais Renováveis (1994), Lagosta, caranguejo-uçá e camarão no Nordeste. Série Estudos Pesca. Coleção Meio Ambiente, Brasília, pp. 107-140.

Islam, M.S. and Tanaka, M. (2004), Impacts of pollution on coastal and marine ecosystem including coastal and marine fisheries and approach for management: a review and synthesis. Mar. Poll. Bull., 48, 624-649.
Jackson, T.C., Acuff, G.R., Dickson, J.S. (1997), Meat, poultry, and seafood. In: Doyle, M.P., Beuchat, L.R., Montville, T.J. (Eds.). Food Microbiology Fundamentals and Frontiers, ASM, Washington, DC. Jay, J.M., Loesner, M.J., Golden, D.A. (2005) Modern Food Microbiology, 7th ed., Chapman and Hall, New York, USA.

Kjerfve, B., Lacerda, L.D., Diop, S. (1997), Mangrove Ecosystem Studies in Latin America and Africa. Unesco, Paris.

Lima, T.C.S. and Gorlach-Lira, K. (2007), Occorência de bactérias patogênicas em carne de caranguejo (Ucides cordatus) comercializada em feiras-livres de João Pessoa e Cabedelo, PB. Rev. Hig. Alim., 21, 6571.

Lorch, H.J., Benckieser, G., Ottwi, J.C.G., (1995), Basic methods for counting microorganisms in soil and water. In: Alef, K. and Naninipieri, P. (Eds.). Methods in applied soil microbiology and biochemistry. Academic Press,London, pp. 146-161.

Reheinheimer, G. (1997), The influence of natural salinity gradients on bacteria communities of flowing waters. Limnol., 27(1), 29-35.

Ristori, C.A., Iaria, S.T., Gelli, D.S., Rivera, I.N. (2007), Pathogenic bacteria associated with oysters (Crassostrea brasiliana) and estuarine water along the south coast of Brazil. Int. J. Environ. Health Res., 17(4), 259-269.

Robson, A.A., Kelly, M.S., Latchford, J.W. (2007), Effect of temperature on the spoilage rate of whole, unprocessed crabs: Carcinus maenas, Necora puber and Cancer pagurus. Food Microbiol., 24(4), 419-24.

Tam, N.F.Y. (1998), Effects of wastewater discharge on microbial populations and enzyme activities in mangrove soils. Environ. Pollution, 102, 233-242.

Thomas, A., Straif-Bourgeois, S., Sokol, T.M., Ratard, R.C. (2007), Vibrio infections in Louisiana: twentyfive years of surveillance 1980-2005. J. La State Med. Soc., 159(4), 205-8, 210-1.

Vieira, R.H.S.F., Lima, E.A., Sousa, D.B.R., Reis, E.F., Costa, R.G., Rodrigues, D.P. (2004), Vibrio spp. and Salmonella spp. presence and susceptibility in crabs Ucides cordatus. Rev. Inst. Med. Trop. S. Paulo, 46, 179-182.

Wolff, M., Koch, V., Isaac, V. (2000), A trophic flow model of the Caeté Mangrove Estuary (North Brazil) with considerations for the sustainable use of its resources. Estuar. Coast. Shelf Sci., 50, 789-803.

Received: November 01, 2007; Revised: August 26, 2008; Accepted: July 31, 2009. 